\title{
Teachers' Perspectives about the Effect of Tawjihi English Exam on English Instruction at the Second Secondary Stage in Jordan
}

\author{
Dr. Mohammad Abd Alhafeez Ali Ta'amneh \\ Assistant Professor of Teaching English as a Foreign Language (TEFL) \\ Taibah University \\ E-mail: Taamnehmohammad@yahoo.com
}

Received: July 3, 2014 Accepted: July 18, 2014 Published: July 19, 2014

doi:10.5296/ijele.v2i2.5995 URL: http://dx.doi.org/10.5296/ijele.v2i2.5995

\begin{abstract}
The present study aimed to explore Teachers' perspectives about the effect of Tawjihi English Exam (hereafter TEE) on English Instruction at the Second Secondary Stage in Jordan. Two samples were selected. The first one consisted of 205 EFL teachers who responded to the questionnaire, and the second sample consisted of 25 EFL teachers who were purposefully selected to be interviewed in their schools during the academic year 2013-2014. Results showed that teachers did not believe in the effectiveness of TEE in developing learners' English language skills. Besides, they agreed that TEE did not have positive effects in future English learning.
\end{abstract}

Keywords: Teachers' perspectives, Tawjihi English Exam, English Instruction, Second Secondary Stage 


\section{Introduction}

Examination is considered as one of the essential components of any curriculum. It is very important in determining the progress of learners in learning process and deciding the methods of teaching used by instructors. Learners learn better when they are aware of how their efforts are to be assessed and evaluated (Candlin and Edelhoff 1982). Furthermore, examination plays a vital role in improving the process of learning. Gipps (1994) claims that the major purpose of examination is to support the process of teaching and learning, but some forms of it can clearly impede deep learning. Agrawal (2004) states that English is shifting from the traditional structure-based curriculum to an activity based curriculum which promotes appropriateness, accuracy and fluency in using English language and improves learners' skills in English language skills. She mentions that the proponents of evaluation reform think that tasks such as multiple-choice tests have a restricting effect on the curriculum and methods of teaching. She adds that this kind of evaluation encourages teachers to teach students test-taking skills rather than develop metacognitive skills and understandings.

In the past, EFL classes concentrated on some English skills and forgot others; each skill did not interact with others. Rather, these segregated-skill-oriented courses had language itself as the focus of instruction to the extent that excessive emphasis on rules and paradigms taught students a lot about language at the expense of teaching language itself (Brown, 2000: 218). Recently, a trend toward skill integration has developed. Curriculum designers and instructors have recognized the importance of integrating English language skills. According to Brown (2000), the richness of integrated English skill courses give learners motivation to better retention of principles of effective skills.

Jordan, like many other countries, looks forward to developing its educational system which has witnessed a comprehensive reform at all levels. It has realized that English language is an essential means of communication between Jordan and other countries of the world. The educational system is now provided with contemporary technical aids, textbooks and guidelines for current teaching methods. Recently, the Ministry of Education has adopted a new English program for all grades in Jordan called ACTION PACK to improve the quality of English learning (Ta'amneh 2005). The purposes of this series are to improve the quality of teaching, to develop the students' skills to a level that they will enable them to use English independently and to enrich their knowledge in various fields (Alomari, 2002).

Action Pack 12 is described as a communicative English course. It is prepared to be taught in Jordanian schools for the Second Secondary stage. It helps students learn English and encourages them to become confident users of English. It also offers learners modern, interesting, and relevant topics, a clear and systematic approach to grammar, with thorough practice, integrated skills work with a particular focus on reading and writing, consistent building and recycling of vocabulary, special sections devoted to functional and situational language, project work at the end of every module and the development of critical thinking skills . It consists of a Students' Book, Audio Cassettes, a Workbook and a comprehensive Teacher's Book. It consists of two levels; level 3 and level 4 (Haines 2010). At the end of 
each level there is an exam called Tawjihi English Exam. It is the general secondary examination in Jordan intended by the Ministry of Education.

The Tawjihi English Exam consists of two papers; the first one has two main parts: reading comprehension and vocabulary, and the second paper has three main parts: language, literature, and composition. Its structure and content are totally based on the curriculum of the Second Secondary class.

\subsection{Statement of the Problem}

Students who attended Tawjihi English Exam complain that they are not tested in what they studied at schools in English because the objectives of the English language curricula are not reflected in the test. Besides, they claim that this exam does not help them in their future learning since it concentrates on some English skills and forget others (Bani Abdelrahman 2010). This study explored the teachers' responses about the effect of this exam (TEE) on English instruction at the second secondary stage in Jordan. So, the study aimed to answer the following questions:

1-What are the Jordanian teachers' beliefs about the effect of Tawjihi English Exam on English instruction?

2-What are the Jordanian teachers' beliefs about the effect of Tawjihi English Exam on the students' future English learning?

\subsection{Significance of the Study}

The Jordanian Ministry of Education introduced Action Pack 12 in 2010. The first general examination was administered in 2010 as it was the first year when Action Pack 12 was used. However, the significance of this study stems from the fact that, as far as the researcher knows, there are not many studies investigating Teachers' ideas and thoughts about the effect of TEE on the students' future learning. So, this study may:

1-Provide the examination writers with useful information about the effectiveness of TEE.

2-Give instructors and curriculum designers practical implication for developing learners' growth in EFL learning.

\section{Review of Related Literature}

This part reviews what researchers say about Tawjihi English Exam. In addition, it talks about teachers' opinions about this kind of examination in determining approaches to the process of teaching and learning.

Harrison, Prator and Tucker (1975) surveyed the Jordanian state of English system. They indicated that the final English language achievement of each school graduate was evaluated by student's success in the General Secondary Certificate Examination in English. The form of this exam affected the methods of teaching English for students. In addition, the examination did not evaluate students' listening and speaking comprehension, but it measured their reading and writing skills. They added that the lack of correspondence between the 
specific objectives in the curriculum and this kind of examination would just make students attention to prepare to pass the required examination.

Bani Abdelrahamn (2003) investigated the General Secondary Certificate Examination in Jordan through evaluating the extent to which English language teaching objectives were realized in the GSCE in Jordan between 1997 and 2002 and to build up a guide for the curriculum designer, teachers and examination writers of the GSCE in English. The sample of the study consisted of all examination papers of the GSCE in English in Jordan between the years 1997 and 2002. The findings revealed that the objectives of listening and speaking were not available in the GSCE completely, fifty percent of the reading objectives, forty percent of the writing objectives, and twenty four percent of the functions were available in the GSCE.

Haddadin, Dweik and Sheir (2008) examined teachers' and students' perceptions of the effect of public examinations on English instruction at the Jordanian secondary stage. The researchers used survey questionnaires for teachers and students in this study. Besides, interviews were used to discuss teachers' and students' perceptions about the effect of the national test on their instruction. Findings showed a relatively high percentage for the effect of the national test on instruction. In addition, the students' questionnaire showed the same result which was related to the effect of the exam on the their learning. Both teachers and students were affected by the content and the format of the national test. The process of teaching and learning were oriented towards passing the national test without looking to listening and speaking skills. The researchers recommended teachers to take into consideration to use alternative assessment tools to reflect positive washback on the instruction of the English language skills.

Al-Shaer (2010) examined the impact of the Tawjihi English Exam (TEE) on the practices of English language teachers and students in the writing classroom in Palestine. The researcher found that both teachers and students worked hard for the TEE. Moreover, the majority of teachers gave their students writing tasks taken from previous Tawjihi writing tests. In addition, most students left the writing sections in their textbooks that were thought to be not important for their exam. He added that the students' and teachers' opinions went on the importance of five main aspects of writing which were mechanics, accuracy, content, organization, and context/appropriateness. Results also showed that the Tawjihi English Exam shaped what happened in the English writing classroom.

Bani Abdelrahman (2010) investigated the General Secondary Certificate Examination through assessing to what extent English Language Teaching Objectives were available in the General Secondary Certificate Examination in Jordan between 2008 and 2010. His sample consisted of all examination papers of the GSCE in English in Jordan between 2008 and 2010. Results revealed that the objectives of listening and speaking were not available, completely, two out of three of the reading objectives were available, four out of five of the writing objectives were available in the General Secondary Certificate Examination.

\section{Methodology}

\subsection{Population and Sample}


The population of the study, which included 430 EFL teachers consisted of all teachers in Irbid First Directorate of Education during the academic year 2013/2014. Two samples were selected to participate in this study. The first one consisted of 205 EFL teachers who were randomly chosen from the population. The second sample consisted of 25 EFL teachers who teach Action Pack 12 for the second secondary students. The members of this sample were selected purposefully from the population to be interviewed in their schools.

\subsection{Instruments of the Study}

For the purpose of obtaining information needed to achieve the objectives of the study, the researcher adopted the questionnaire found in Haddadin, Dweik and Sheir (2008). The purpose of this questionnaire was to reveal the teachers' perceptions about the effect of TEE on English instruction at the second secondary stage in Jordan. The dimensions and statements of the questionnaires were relevant to research and literature review. The researcher also developed a number of interview questions to be answered by the teachers. The purpose of the questions was to get more information about teachers' perceptions and beliefs about the effect of TEE on future English learning for the second secondary students. The participants provided the researcher with information through verbal interchange and conversation. The interviewees were asked a variety of questions to elicit the information most possible in the time available.

\subsection{Validity of the Interview Questions}

To ensure the validity of the interview questions, the jury of EFL specialists was asked to judge whether the questions were appropriate and comprehensive. The jury suggested editing some of the questions. The researcher edited them accordingly.

\subsection{Procedures}

In this study, the researcher used qualitative and quantitative approach. The means, percentages, and standard deviation of each item in the questionnaires were analyzed using appropriate statistical techniques to determine the teachers' perceptions about the effect of this exam (TEE)on English instruction at the second secondary stage.

\section{Discussion of the Results}

Results of the first question was about the Jordanian teachers' beliefs about the effect of Tawjihi English Exam on English instruction. The means and the standard deviations were calculated. Table 1 presents the results.

Table 1. Means, percentages and standard deviations for each item of the teachers' questionnaire.

\begin{tabular}{|l|l|l|l|l|}
\hline & Items & M & per & S.D \\
\hline 1 & $\begin{array}{l}\text { If the GSCE were cancelled, subject or skill emphasis in teaching } \\
\text { would be different. }\end{array}$ & 4.52 & $90 \%$ & .599 \\
\hline 2 & $\begin{array}{l}\text { I give more time to grammar instruction than the communicative } \\
\text { skills because it is tested on the GSCE. }\end{array}$ & 4.67 & $93 \%$ & .574 \\
\hline
\end{tabular}




\section{Macrothink}

International Journal of English Language Education

ISSN 2325-0887

2014, Vol. 2, No. 2

\begin{tabular}{|c|c|c|c|c|}
\hline 3 & I teach test-taking strategies to the secondary classes. & 4.76 & $95 \%$ & .663 \\
\hline 4 & My planning and instruction are influenced by the teaching time. & 4.27 & $85 \%$ & .859 \\
\hline 5 & My teaching methods are influenced by what is tested on the GSCE. & 4.33 & $87 \%$ & .698 \\
\hline 6 & The GSCE has little impact on how I teach. & 4.02 & $80 \%$ & .376 \\
\hline 7 & $\begin{array}{l}\text { I rarely change my teaching methods and strategies to help my } \\
\text { students succeed in the GSCE. }\end{array}$ & 2.32 & $46 \%$ & .651 \\
\hline 8 & Students' learning abilities influence my teaching. & 3.38 & $77 \%$ & .487 \\
\hline 9 & $\begin{array}{l}\text { I use additional commercial books because they help my students } \\
\text { succeed in the GSCE. }\end{array}$ & 2.30 & $46 \%$ & .606 \\
\hline 10 & $\begin{array}{l}\text { I provide my students with worksheets to review content expected to } \\
\text { be in the GSCE. }\end{array}$ & 4.81 & $96 \%$ & .390 \\
\hline 11 & $\begin{array}{l}\text { I have my students do the Ministry of Education mock tests to } \\
\text { familiarize them with the GSCE. }\end{array}$ & 4.24 & $85 \%$ & .494 \\
\hline 12 & $\begin{array}{l}\text { I supply my students with software programs and special media to } \\
\text { help them prepare for the exam. }\end{array}$ & 1.88 & $38 \%$ & 610 \\
\hline 13 & I just employ "the chalk and talk" in my teaching. & 3.93 & $79 \%$ & 630 \\
\hline 14 & $\begin{array}{l}\text { The GSCE affects my syllabus, including practicing the components } \\
\text { of the language that are to be tested. }\end{array}$ & 4.45 & $89 \%$ & .769 \\
\hline 15 & I pay little attention to the GSCE while preparing my lesson plans. & 2.32 & $46 \%$ & .750 \\
\hline 16 & $\begin{array}{l}\text { I emphasize the skills which are more likely to be tested on the } \\
\text { GSCE while planning for my syllabus. }\end{array}$ & 4.48 & $90 \%$ & .538 \\
\hline 17 & $\begin{array}{l}\text { I skip over certain sections in the textbook because they are not } \\
\text { tested on the GSCE. }\end{array}$ & 4.17 & $83 \%$ & .966 \\
\hline 18 & The GSCE has little impact on what I teach. & 2.24 & $45 \%$ & $\begin{array}{l}1.01 \\
4\end{array}$ \\
\hline 19 & $\begin{array}{l}\text { I cover all the skills in the textbook: Reading, Vocabulary, Structure, } \\
\text { Writing, Listening and Speaking. }\end{array}$ & 1.66 & $33 \%$ & .823 \\
\hline 20 & $\begin{array}{l}\text { I would teach what I think is important whether my students like it or } \\
\text { not. }\end{array}$ & 1.92 & $38 \%$ & .632 \\
\hline 21 & $\begin{array}{l}\text { I rarely use specific teaching activities to promote my students' } \\
\text { language skills just for the GSCE. }\end{array}$ & 2.47 & $49 \%$ & $\begin{array}{l}1.47 \\
0\end{array}$ \\
\hline 22 & $\begin{array}{l}\text { I arrange my classroom activities according to the objectives of the } \\
\text { GSCE. }\end{array}$ & 4.34 & $87 \%$ & .735 \\
\hline 23 & $\begin{array}{l}\text { The GSCE stimulates me as a teacher to apply activities which } \\
\text { promote my students' test-taking skills. }\end{array}$ & 4.52 & $90 \%$ & .539 \\
\hline 24 & $\begin{array}{l}\text { I evaluate my students' assignments by using the criteria used by } \\
\text { examiners when marking the GSCE. }\end{array}$ & 3.87 & $77 \%$ & .964 \\
\hline 25 & $\begin{array}{l}\text { I adopt test items from the Ministry of Education tests in my } \\
\text { classroom quizzes. }\end{array}$ & 4.53 & $91 \%$ & .764 \\
\hline 26 & $\begin{array}{l}\text { My evaluation is mostly based upon the students' written works: } \\
\text { reading comprehension text, vocabulary, structure and writing. }\end{array}$ & 4.04 & $81 \%$ & .962 \\
\hline
\end{tabular}






Table 1 shows the most common beliefs among teachers about the effect of Tawjihi English Exam on English instruction. EFL teachers believe that they should help students in passing this kind of examination through providing students with worksheets to review content expected to be in the TEE, teaching test-taking strategies, giving more time to grammar instruction than the communicative skills, adopting test items from the Ministry of Education tests in classroom quizzes, applying activities which promote students' test-taking skills, changing skill emphasis in teaching English if they had choice, emphasizing skills tested on the TEE while planning for their syllabuses, practicing the components of the language that are to be tested. They also think that the TEE does not able to test students' language abilities since the evaluation is mostly based upon the students' written works: reading comprehension text, vocabulary, structure and writing. Besides, they consider that their teaching methods, instructions, activities, and even assessments are arranged according to the objectives of TEE. The findings reached by this study have shown that the TEE has a large effect on English instruction. It was clear that TEE influence the process of English teaching in the second secondary stage. Teachers' time management, methods and strategies, instructional materials, and assessment procedures were influenced, categorized, and arranged according to the TEE. The results of the first question showed that TEE had a great effect on English instruction in the Second secondary class. This result agrees particularly Haddadin, Dweik and Sheir (2008), Bani Abdelrahamn (2003) and Bani Abdelrahman (2010).

Results of the second question was about the Jordanian teachers' beliefs about the effect of Tawjihi English Exam on English future instruction. Most of the interviewed teachers think that TEE is very important exam since it shapes the students' future learning. The importance of this exam stems from the fact that it represents a significant turning point in the life of every second secondary student in Jordan. The student has to take and pass this exam in order to have the second secondary certificate and complete his/her studying. Concerning the integration of four language skills in TEE, all of the them think that TEE does not have questions related to the listening and speaking. It consists of questions related to the reading and writing skills. They believe that the ultimate goal for the second secondary students is to pass the exam not to learn English. So teachers and students do not look for learning English language, they look for passing this exam with a high grade. According to strategies used in their teaching, they use test-taking strategies in their teaching (giving more time to grammar instruction than the communicative skills and adopting test items from the Ministry of Education tests in classroom quizzes) since the purpose of TEE is to pass this stage not to learn English language. Evaluating students' achievement based on the questions found in TEE. Their questions based upon the students' written works: reading comprehension text, 
vocabulary, structure and writing. All interviewed teachers believe that TEE may help secondary students in developing reading and writing skills, but it does not give them any information about listening and speaking skills. Accordingly, students may find many obstacles in their university learning since the university English learning is totally different from secondary learning in terms of strategies, objectives, aims, content and evaluation. The results of Harrison, Prator and Tucker (1975) Haddadin, Dweik and Sheir (2008), Bani Abdelrahamn (2003) and Bani Abdelrahman (2010) confirm the results to which the present study ends up.

\section{Conclusion}

This study explored the most common beliefs among teachers about the effect of Tawjihi English Exam on English instruction at the Second Secondary Stage in Jordan. It also showed that this exam does not help students in developing English language skills since its questions related to the reading and writing and forget the listening and speaking skills.

\section{References}

Agrawal. M. (2004). Curricular Reform in Schools: The Importance of Evaluation. Curriculum Studies, 36(3), 361-379. http://dx.doi.org/10.1080/0022027032000152987

Al-Shaer, I. (2010) Impact of the Writing Component of the Tawjihi English Exam on the Classroom Practices in Palestine. Retrieved from http://www.qou.edu/arabic/researchProgram (June 24, 2011).

Bani Abdelrahman, M. (2010). An Analysis of "Jordan Opportunities" Objectives in the General Secondary Certificate Examination of English: A Case Study in Jordan between 2008 and 2010. Asian Social Science, 6, 11.73-87.

Brown, H. Douglas. (2001). Teaching by Principles: An Interactive Approach To language Pedagogy. Second Edition, San Francisco Public University.

Candlin, C., \& Edelhoff, C. (1982). Challenges: Teacher's Guide. (London: Longman).

Gipps, C. (1994). Beyond Testing: towards a theory of educational assessment, Lewes. Falmer Press.

Haddadin, A., Dweik, B., \& Sheir, A. (2008). Teachers' and Students' Perceptions of the Effect of Public Examinations on English Instruction at the Secondary Stage in Jordan. The Jordan Journal of Applied Science ,11, 2. 331-344.

Harrison, W., Prator, C., \& Tucker G. (1975). English Language Policy Survey of Jordan. Center for Applied Linguistics, U.S.A.

Simon. H. (2010). Action Pack 12: Student's book. York Press: London, England. 


\section{Appendixes}

\section{Appendix 1. The Teachers' Questionnaire}

The researcher aims at investigating EFL teachers' perspectives about the effect of Tawjihi English Exam on English instruction at the second secondary stage in Jordan. You are kindly asked to complete this form and to put a tick beside the response which most matches your belief. Your responses will be confidential and used for academic research purposes. You are kindly asked to put a tick $(\sqrt{ })$ in the space which most corresponds to your degree of agreement with each of the following statements:

\begin{tabular}{|c|c|c|c|c|c|c|}
\hline & Items & $\begin{array}{l}\text { S. } \\
\text { agree }\end{array}$ & agree & $\begin{array}{l}\text { Neutr } \\
\text { al }\end{array}$ & $\begin{array}{l}\text { disagre } \\
\mathrm{e}\end{array}$ & $\begin{array}{l}\text { S. } \\
\text { disagre } \\
\text { e }\end{array}$ \\
\hline 1 & $\begin{array}{l}\text { If the GSCE were cancelled, subject or skill } \\
\text { emphasis in teaching would be different. } 1\end{array}$ & & & & & \\
\hline 2 & $\begin{array}{l}\text { I give more time to grammar instruction than } \\
\text { the communicative skills because it is tested on } \\
\text { the GSCE. }\end{array}$ & & & & & \\
\hline 3 & $\begin{array}{l}\text { I teach test-taking strategies to the secondary } \\
\text { classes. }\end{array}$ & & & & & \\
\hline 4 & $\begin{array}{l}\text { My planning and instruction are influenced by } \\
\text { the teaching time. }\end{array}$ & & & & & \\
\hline 5 & $\begin{array}{l}\text { My teaching methods are influenced by what is } \\
\text { tested on the GSCE. }\end{array}$ & & & & & \\
\hline 6 & The GSCE has little impact on how I teach. & & & & & \\
\hline 7 & $\begin{array}{l}\text { I rarely change my teaching methods and } \\
\text { strategies to help my students succeed in the } \\
\text { GSCE. }\end{array}$ & & & & & \\
\hline 8 & $\begin{array}{l}\text { Students' learning abilities influence my } \\
\text { teaching. }\end{array}$ & & & & & \\
\hline 9 & $\begin{array}{l}\text { I use additional commercial books because they } \\
\text { help my students succeed in the GSCE. }\end{array}$ & & & & & \\
\hline 10 & $\begin{array}{l}\text { I provide my students with worksheets to } \\
\text { review content expected to be in the GSCE. }\end{array}$ & & & & & \\
\hline 11 & $\begin{array}{l}\text { I have my students do the Ministry of } \\
\text { Education mock tests to familiarize them with } \\
\text { the GSCE. }\end{array}$ & & & & & \\
\hline 12 & $\begin{array}{l}\text { I supply my students with software programs } \\
\text { and special media to help them prepare for the } \\
\text { exam. }\end{array}$ & & & & & \\
\hline 13 & $\begin{array}{l}\text { I just employ "the chalk and talk" in my } \\
\text { teaching. }\end{array}$ & & & & & \\
\hline 14 & The GSCE affects my syllabus, including & & & & & \\
\hline
\end{tabular}




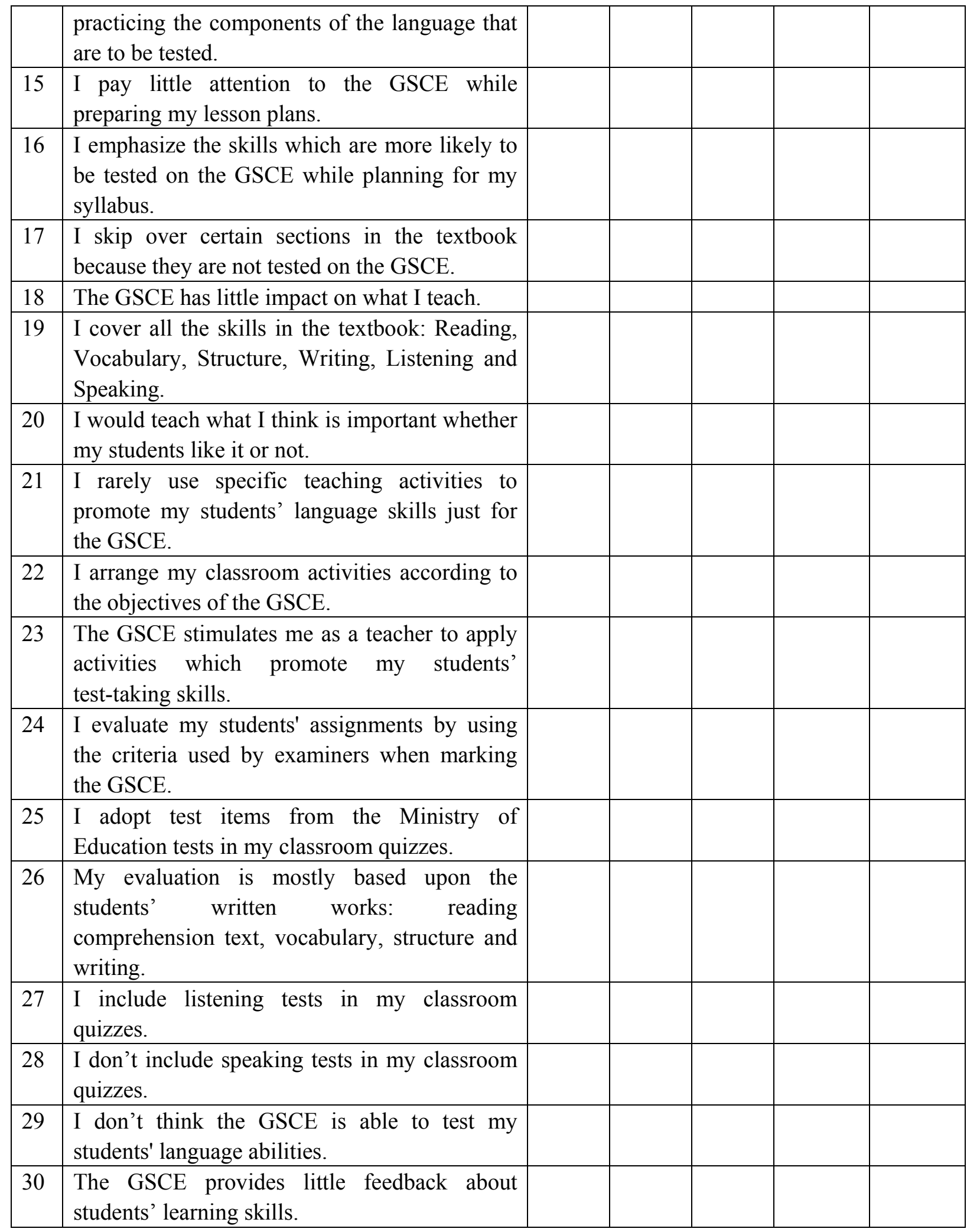




\section{Appendix 2. The Interview}

Interviewer: Dr. Mohammad Abd Alhafeez Ali Ta’amneh

Assistant Professor of TEFL

Taibah University.

Interviewee's name:

Please note that your responses will be solely used for the study purposes. Information provided will be kept confidential and discarded upon the completion of the study. You also have the right to withdraw from participating in or answering any interview questions.

Thank you for your willingness and time.

\section{Section One: Background Information}

Date:

Location:

Time :

Section Two: Teachers' perspectives about the Effect of Tawjihi English Exam on English Instruction at the Second Secondary Stage in Jordan.

1-What is your viewpoint about Tawjihi English Exam?

2-Are topics in TEE arranged to be taught in terms of four language skills?

3-What is your viewpoint about the strategies used to achieve the objectives of TEE?

4-How do you evaluate your pupils`achievement?

5-Do you think that TEE help students in their future learning?

\section{Copyright Disclaimer}

Copyright for this article is retained by the author(s), with first publication rights granted to the journal.

This is an open-access article distributed under the terms and conditions of the Creative Commons Attribution license (http://creativecommons.org/licenses/by/3.0/). 